\title{
Is the public sector at the centre of the class struggle?
}

\section{Professor Roger Seifert}

\section{Abstract:}

Public sector workers are workers even though they are not employed by profitmaking firms. As a consequence their unions are part of the working-class movement. Working for state-owned and managed services does not detract either from their class position or from the need for their unions to defend and improve their terms and conditions. In the current UK situation with politically-engineered 'austerity' (budget, wage, and pension cuts) and the application of tougher performance management systems in the public services (New Public Management), their struggles can be seen to be one centre of the wider class struggle.

Key words: public sector; workers; unions; class struggle.

\section{Introduction:}

This essay provides a brief overview of the role of the state, and then argues that all workers that sell their labour power in a labour market are part of the working-class, and seeks to diffuse the argument that only workers working in the private-for-profit sector are exploited and therefore are in some sense 'true' workers. The struggles by public sector workers have taken on a sharper focus in recent years with the rolling out of more neo-liberal programmes ${ }^{1}$ due to budget and pay cuts, ${ }^{2}$ pension reforms, ${ }^{3}$ the implementation of New Public Management (NPM) practices, ${ }^{4}$ and the

\footnotetext{
${ }_{1}^{1}$ Noam Chomsky, Profit over People, (Seven Stories Press, 1999).

${ }^{2}$ Annual Survey of Hours and Earnings 2016, Office for National Statistics

3 John Hutton, Independent Public Service Pensions Commission: Final Report, (HM Treasury 2011).

${ }^{4}$ Christopher Hood, 'A public management for all seasons?', Public administration 69:1 (1991), 3-19; Christopher Hood, 'The "New Public Management" in the 1980s: variations on a theme', Accounting, organizations and society, 20:2-3 (1995), 93-109.
} 
consequences in terms of an altered labour process with work intensification, routinisation, and a weaker role for collective bargaining and representation. ${ }^{5}$

Once this is established then, naturally, public sector workers can belong to trade unions and struggle to protect and improve their terms and conditions of service just the same as all other workers. This essay ends with a comment on struggle and resistance in terms of industrial action, campaigns, and the mobilisation of counterveiling powers at work and beyond. ${ }^{6}$

\section{The role of the state and state ownership:}

The classical Marxist notion of the state remains of interest. ${ }^{7}$ Namely that the state, as understood in terms of both apparatus and institutionalised power and authority, is used by the pro tem ruling class (capitalists under capitalism) as an instrument of class rule. This involves defining the hegemonic national interest (including the national economy) in terms of the interests of the ruling class: regulating to various degrees non-state organisations including, inter alia, privately owned companies, trade unions, and religious bodies; providing policy directives, and controlling ideological disposition. ${ }^{8}$ So the BBC is asked to be business-friendly and Universities to be business-facing, the police are asked to prioritise property theft above personal abuse, and health care focusses more on the economically active than on the needs of every patient. At the same time the state seeks to oppress its opponents. In a liberal democracy this may be sotto voce, but union activity is restricted, left wing views ignored or derided, and foreign leftist governments frequently demonised.

\footnotetext{
${ }^{5}$ Roger Seifert, The good, the bad, and the future (CLASS 2014).

${ }^{6}$ Leo Panitch, 'Trade unions and the state', New Left Review 125 (1981), 21-44.

7 Karl Marx and Frederick Engels, The German Ideology, (Selected Works volume 1, Progress Publishers 1969 edition, 1846); Vladimir Lenin, The state and revolution, (Lawrence \& Wishart 1917, 1969 edition), pp. 264-350; Ralph Miliband, The state in capitalist society, (Quartet Books 1973).

${ }^{8}$ Antonio Gramsci, 'State and civil society', especially pp. 245-264, in Prison Notebooks. (Lawrence \& Wishart 1971 edition,1929-1935).
} 
Part of this is the extent to which the state directly and/or indirectly owns and controls aspects of civil society. In the UK, for example, from the late 1940s to the mid-1980s there was significant expansion in welfare-related public services such as health, education, local and central government, and emergency provision (police, fire, and ambulance). This post-war consensus for both practical and political reasons took on the form of state-directed services with the argument that some form of integrated planned and sustainable provision was best met through public ownership. This argument was extended to the utilities (water, gas, electric, and phone), to sections of transport (rail, buses, roads), and into extraction (coal) and manufacture (steel, cars). ${ }^{9}$

Experience showed that public ownership was a necessary but not sufficient condition for well operated and planned activities, and that insufficient interest was shown in the management of the enterprises, the role of unions, the importance of the citizen-user, and the level of actually existing integrated planning. The dialectics of public ownership became clear with, on the one hand, state-funded investment and changeable operational priorities set to support the private sector, and on the other hand genuine intentions to use such services for the common good. In practice this was not always achieved due to failures to deal with vested interests, lack of integrated planning, the continuing democratic deficit (never resolved), and the neglect of the needs of citizen-users (mainly not voiced). In the end many providers became a by-word for delay and indecision, bureaucracy and self-serving senior managers, and callous planning and indifference to citizen concerns. ${ }^{10}$ Thus the nonservice parts of state ownership were easy prey to the combination of predatory

\footnotetext{
${ }^{9}$ Kenneth Morgan, Britain since 1945: the people's peace (OUP 2001).

${ }^{10}$ Ben Fine. 'Scaling the commanding heights of public enterprise economics'. Cambridge Journal of Economics, 14:2 (1990), 127-142.
} 
capitalists seeking to profit from privatisation, senior managers eyeing higher salaries, a disillusioned public, and so-called free market ideologues. This partly explains the apparent ease with which gas and electricity, and later rail, coal, and water were privatised. ${ }^{11}$ There was fierce opposition from some unions, concerned user groups, and others on the left, but they fought a losing battle against the powerful forces of privatisers backed by Thatcher supporters and an increasingly disappointed and indifferent set of users. ${ }^{12}$

By the early 1990s, under the Major governments, this privatisation trend was extended to services, and later continued under New Labour with the endorsement of such moves through, inter alia, PFI financing, selling public assets, outsourcing, and fake performance systems especially in local and central government. ${ }^{13}$ The ideological revolution was apparently complete, and with it the fragmentation of units of provision based on ideals of supply-side economics: NHS Trusts, civil service agencies, academy schools, stand-alone Universities and FE colleges, patient transport service, and private prisons. "Hence the 'privatisation' movement worldwide is rooted, apparently, in the failings of state provision through government agencies due to a variety of causes. The main one cited by right wing think tanks (such as Policy Exchange, Adam Smith Institute, Centre for Policy Studies), and politicians is the intrinsically inefficient nature of state provision due to lack of market competition. But there are more specific objections to state provision which include some familiar

\footnotetext{
${ }^{11}$ Joel Wolfe, 'State Power and Ideology in Britain: Mrs Thatcher's Privatization Programme', Political Studies 39:2 (1991), 237-252.

${ }^{12}$ For example, see Stewart Black, 'What's happening to water and sewerage services in Scotland?', Scottish Affairs 6:1 (1994), 25-35

${ }^{13}$ Stuart Wilks-Heeg, 'New Labour and the Reform of English Local Government, 1997-2007: Privatizing the Parts that Conservative Governments Could Not Reach?' Planning Practice \& Research 24:1 (2009): 23-39
} 
hypotheses based on a mixture of neo-liberalism ..., public choice theory ..., and new public management ...". ${ }^{14}$

The fight to keep services in the public domain is rooted in deeply held views of what a just society looks like, ${ }^{15}$ as well as the dangers to service provision from the anarchic and chaotic ways in which the private sector operates. ${ }^{16}$ This instability tendency within the capitalist mode of production, with its periodic crashes, meant that there was widespread support for state provision of health, education, environmental protection, social services, public spaces, emergency services, and civil services. The case for state ownership and management of economic and social aspects of communal life are increasingly central to contemporary debates about the present and future direction of economic and social policy programmes. They form part of the policy direction associated with growing inequality, not only of wealth and income, but of access to the necessaries of a civilised life. ${ }^{17}$

None of this movement to privatize has been seen to save money, improve services, or maintain the socially positive role of these services in the life of the nation. The public face of such policy programmes have been riddled with contradictions, false economies, and failures ... the slogan has been more of the same alongside 'more for less'. Such nostrums began to undermine the fragile employment relationship that had dominated public service work in the post-war settlement.

The promise to public sector workers implicitly made by state authorities and political party leaders since the 1950s had been of job security, guaranteed pensions, 'fair'

\footnotetext{
${ }_{15}^{14}$ Roger Seifert, 2014, p.4

${ }^{15}$ Amartya Sen, The idea of justice, (Harvard University Press, 2011).

${ }^{16}$ Karl Marx, The poverty of philosophy, (Progress publishers 1964 edition, 1847); Victor Perlo, The Unstable Economy, (Lawrence \& Wishart 1973).

${ }^{17}$ Richard Wilkinson and Kate Pickett, The Spirit Level: why equality is better for everyone, (Penguin 2010); Thomas Piketty, Capital in the twenty-first century. (Harvard University Press, 2017); Joseph Stiglitz, The great divide. (Penguin UK, 2015).
} 
pay based on notions of comparability, superior management of labour systems with less discrimination, more transparent promotion, union recognition and wide-spread use of collective bargaining, and accountable senior managers. ${ }^{18}$ These were some of the hallmarks of working for the public sector and aspirations fought for by the relevant trade unions. In practice, of course, the reality was more mixed but overwhelmingly the presupposition was that being employed in the public sector was different, and a good difference, from working in the private profit-making sector. As this situation deteriorated from the mid-1980s such policies and practices gave rise to further class struggle as public sector workers and their unions began their long march against reduced rights at work.

\section{Nature of class and class relations in the public sector:}

Some on the left, even some purporting to be Marxists, have argued that the working class as a class is defined by being exploited by capitalists seeking profits through the extraction of surplus value in the production process. They are correct to emphasise the importance of exploitation under capitalism, but its basis is the nature of the employment contract whereby the workers lack of the means of production force them to contract with the capitalist on terms that allow for the extraction of surplus value. In this sense, therefore, the degree of exploitation can be mediated by the exact terms of the exchange, and hence there is a central role for trade unionism in this process. There is additionally a role for trade unionism in exposing the nature of exploitation as one feature of capitalist means of production is that exploitation is hidden from both the exploited and exploiters some of the time.

This muddled view continues that the value of wages paid is lower than the value created by workers (a version of the labour theory of value), and that the extraction

\footnotetext{
${ }^{18}$ Royal Commission on the Civil Service (Priestley Commission) 1955, Cmnd. 9613, HMSO: London
} 
of surplus value (the act of exploitation) takes place in order to turn the surplus into profit (the realisation problem). Thus workers are exploited and this is their defining characteristic. If this is correct, then when the coal mines were nationalised on January $1^{\text {st }} 1947$ on that exact day, 800,000 coal miners ceased to be exploited by coal owners and now worked for a state owned company, the National Coal Board. If the prior case is true then the coal miners also ceased to be workers, part and members of the working class on that day. It follows that those who were still working in the industry in 1994 when it was sold off, suddenly became workers again. It is difficult to see this argument as anything but as both odd and unhelpful. A variant that tried to accommodate the contradictions in this line was that state owned enterprises acted on behalf of the collective of capital and therefore, as eventually capitalists would profit from a better educated and healthier population, so such workers did produce value (at arms length) and that the surplus was expropriated for profit. This reductio ad absurdum never really convinced.

Cohen correctly sought to decouple some of the logical and empirical points being made through the counter-case that the defining quality of being a worker is not being exploited for profit but having to sell your labour power (quality and quantity) in a labour market in order to live: 'the relationship between the labour theory of value and the concept of exploitation is one of mutual irrelevance. The labour theory of value is not a suitable basis for the charge of exploitation laid against capitalism by Marxists' ${ }^{19}$ The notion here allows that the whole design of civil society is to force the propertyless (the mass of workers) into the labour market to exchange labour

\footnotetext{
${ }^{19}$ Gerald A. Cohen, 'The labor theory of value and the concept of exploitation', Philosophy \& Public Affairs (1979), 338-360, p.338; Gerald A. Cohen, 'More on exploitation and the labour theory of value', Inquiry 26.3 (1983), 309-331; Gerry Cohen, Karl Marx's theory of history: a defence, (Clarendon Press 1978). pp 40-45
} 
power for wages as income ${ }^{20}$ The state, acting on behalf of the capitalists, regulates the labour market in various ways, but mainly designed to disadvantage the sellers in favour of the buyers of labour. In other words there is inequality of power before, during, and after workers enter the labour market and employment. ${ }^{21}$ It is this that gives rise to exploitation and not the extraction of surplus for profit per se. It would be a weird contradiction if those on the left in politics opposed privatisation and supported nationalisation, were told by those that profess to the muddled account of exploitation being only extraction of a surplus for profit, that such a set of policies wanted to reduce the working-class! Also if they are not workers because their labour power is not exploited for profit, what are they?

This structural definition of class fits better with Marx's analysis: "it defines the class with reference to the position of its members in the economic structure, their effective rights and duties within it. A person's class is established by nothing but his [sic] objective place in the network of ownership relations". ${ }^{22}$ It follows from this that being a 'class-in-itself' as opposed to a 'class-for-itself' is a central element in the form of class struggle. ${ }^{23}$ This gives rise to the important role of trade unions as organisations with the potential to develop both class consciousness and class struggle. Areas that combine the here-and-now demands for better pay and conditions with recognition of power imbalance as between organised labour and organised capital, in all its forms. The ownership of the enterprise does not necessarily alter the subordinate role of the worker in the production process under dominant capitalist means of production.

\footnotetext{
${ }^{20}$ Karl Marx, Theories of Surplus Value (1862), and Wage Labour and Capital (Selected Works volume 1, Progress publishers, 1969 pages 142-174; 1849)

${ }^{21}$ Henry Phelps Brown, The Inequality of Pay, (OUP 1977).

${ }^{22}$ Cohen 1978 p 73

${ }^{23}$ Karl Marx, The Eighteenth Brumaire of Louis Bonaparte, (Selected Works volume 1, Progress

Publishers,1969, 1869) pp. 394-487
} 
Productive forces remain the same, and therefore, pari passu, exploitation is objectively experienced by all workers who sell their labour power in the market.

The tension as between productive forces and productive relations gives rise to class struggle, seen as the engine of change in societies over time. ${ }^{24}$ But human agency is a necessary element of such change, it is neither inevitable nor pre-determined. The role of political parties, especially revolutionary ones, comes to the forefront of the analysis and as such tactics and strategies, frequently debated and discussed, become one key to unlocking the edifice of power erected by the ruling class ${ }^{25}$ It is such political intervention that allows notions of the balance of class forces and the centre of class struggle to become part of both the debate and the planned activities of the socialist and labour movements. ${ }^{26}$

Struggles inside the public services for better pay and conditions for all staff are allied with calls from them to be allowed to do their jobs --- a reference to both resource shortages and to management teams apparently focussed on priorities not shared by the workforce. It can be argued that fighting for traditional trade union demands means fighting for services that better serve all citizens and can be integrated into a planned service delivery model that is both more efficient and effective than any fragmented part-privatized networked set of disparate services.

Hence the more prosaic debates over tactics - strikes, arbitration, sliding scales, output restrictions - became, as Engels had understood, not simply a question of having some control over hours and wages, but challenging the system under which other workers had to continually challenge to gain anything at all. ${ }^{27}$ This is critical to

\footnotetext{
${ }^{24}$ Karl Marx, Capital (George Allen \& Unwin, 1946; 1867)

${ }^{25}$ Karl Marx and Frederick Engels, The Communist Manifesto (1848)

${ }^{26}$ Vladimir Lenin, What is to be done?, (OUP 1963 edition, 1902)

${ }^{27}$ Frederick Engels, 'Trades Unions', Labour Standard, 28 May and 4 June 1881.
} 
any understanding of the different types of struggle required to confront both the management of limited resources (at any set level), and the battle to increase resources for any given service. Trade unions are involved in both --- the former is mainly a day-by-day conflict over the detailed ways in which limited funds are used and distributed, while the latter involves political coalitions of users and workers to act as pressure groups on political parties.

Taking this case as the more robust logically and empirically, and the one that seems to accord better with what Marx was saying, we end up with a convenient truth: that the working-class as a class, while varied in many ways, shares the fundamental character of having to work to live through the sale of labour power in a market to an employer. In this sense those workers working for non-profit organisations such as charities and the public sector are also exploited and therefore part of the class. Their trade unions are therefore part of the labour movement, their struggles and demands are recognisable across time and place and occupation, and their exploitation and alienation is as tangible and degrading as that of any other worker in any other part of the capitalist economy.

An additional aspect of the argument is the role of the self-employed. The case can be made that all owners of capital (large and small) are capitalists and are not part of the working-class. Since the mid-1990s there has been a steady, and since 2010, an acceleration towards jobs defined as self-employed. Self-employment comes in various forms and increasingly those on so-called fake self-employed contracts (like the lump in the building industry) are, in both an economic and social sense, employees and therefore sell their labour in the market just as other workers. Recent high profile cases as with Uber drivers illustrate this, as the 'gig' economy, takes root. However, some are genuinely self-employed (typically in the building and retail 
trades) and these remain, for now, outside the working-class but also remain as possible allies in certain struggles.

\section{Management changes and the new labour process:}

New Public Management has its origins in the slow resurgence of neo-classical theories of the firm as applied to the state sector. By the 1970s this was a mix of developments that included the principal-agent problem of control, institutional economics, transaction costs, and public choice. ${ }^{28}$ The result was a general restatement of what was wrong with public sector per se, namely that it would by necessity be wasteful (inefficient), unable to reach targets due to bureaucratic tendencies (ineffective), and would misuse funds due to short-term political pressure on politicians (uneconomic).

The remedy, therefore, was to be found in a system (NPM) that embodies the three Es of efficiency, effectiveness, and economy. This was quoted by Mrs Thatcher and others in the 1980 s as the way forward ${ }^{29}$, and gained momentum with the advent of neo-liberal globalisation and the long recession after the 2008 crash. $^{30}$ These real world changes created some of the objective conditions required to implement NPM nostrums as austerity and union weakness allowed a power grab by senior managers in the public sector.

In particular NPM shifts the focus from processes to targeted outcomes, from careers and basic salaries to bonus schemes, and from collaborative labour management practices to oppositional and conflictual. These latter moves came as

\footnotetext{
${ }^{28}$ William Niskanen, 'Nonmarket Decision Making: The Peculiar Economics of Bureaucracy', The American Economic Review, LVII:2 (1967), 293-305; William Niskanen, Bureaucracy and Representative Government, (Aldine-Atherton 1971): 227-9.

${ }^{29}$ Peter Jenkins, Mrs Thatcher's Revolution, (Jonathan Cape 1987)

30 David Kotz, 'The financial and economic crisis of 2008: A systemic crisis of neoliberal capitalism.' Review of Radical Political Economics 41:3 (2009): 305-317.
} 
budget cuts and target regimes required senior managers to reduce pay and conditions and degrade work, and therefore to seek to remove obstacles to this strategic ploy. Such obstacles included trade unions, national collective bargaining, and professional autonomy.

Part and parcel of NPM includes creating atomised units of activity, which may or may not compete against each other for business, outsourcing some services, and allowing senior managers to effectively decide their own remuneration packages. The slogan initially was 'more for less' through the fallacy of efficiency-savings, but this was increasingly shown to be a sham as services crumbled, scandals and crises increased, and organised workers sought common cause with the citizen-user to resist further changes.

The crisis then became one of both the level of resources and the management of resources. Budgets cuts have created false economies, which in turn have meant an increase in the level and intensity of exploitation of workers in these services. The dialectics of top-down managerial controls at the point of production change the labour process of staff through work intensification and deskilling, but at the same time allow for the emergence of new forms of worker resistance as targets have to be met and social media provides instant confirmation of increasingly bad service outcomes.

The labour process of public sector workers has come under pressure in recent years from a combination of management initiatives around NPM, pay and pension cuts, work intensification, a greater range of duties some proscribed by legislation, privatisation, and outsourcing. ${ }^{31}$ Marx spent some time explaining the importance of

\footnotetext{
${ }^{31}$ Harry Braverman, Labor and Monopoly Capitalism, (Monthly Review Press 1974); Karl Marx Capital (volume 1 George Allen \& Unwin 1957 edition, 1867) pp. 156-166.
} 
the labour process and division of labour ${ }^{32}$, and much of the history of the industrialisation period by British Marxist historians explained how the factory system shifted the power relations at work away from workers.

As a result recent Marxist-inspired studies have shown a growing power imbalance at work in public services as between senior managers and staff, a weakening of unions, and an undermining of both professional autonomy and the rights of the individual worker. Key findings revolve around the pressure on workers to work harder (longer hours including unpaid overtime), to work for longer (worse pay and pensions), not to complain (job insecurity and loss of union rights), to accept more inequality and bullying at work, and to accept a loss of control over their work patterns, pace, and contents (Taylorism, Fordism, and Toyotaism).

The nature of work organisation is such that workers are set tasks to complete according to the needs of the service and a set level of labour costs. In the public sector, the struggle over wages ${ }^{33}$ and job regulation ${ }^{34}$, is also a struggle over the type and form of service that is delivered to the citizen-user. Marx argued that as the division of labour intensified so labour became simplified. ${ }^{35}$ With this form of alienation came the tendency to instrumental approaches to the job, namely that workers go to work for wages, and that is all. ${ }^{36}$ With this comes more flexible

\footnotetext{
${ }^{32}$ Karl Marx, Capital (1867) volume 1 parts III and IV, pages 156-365

${ }^{33}$ John Kelly, Rethinking industrial relations: Mobilisation, collectivism and long waves, (Routledge 1999).

${ }^{34}$ Richard Hyman, The political economy of industrial relations: Theory and practice in a cold climate, (Palgrave MacMillan 1989).

${ }^{35}$ Karl Marx, 'Wage-Labour and Capital', Collected Works (Lawrence \& Wishart 1849, 1977 edition) p. 225.

${ }^{36}$ John Goldthorpe, The affluent worker: Industrial attitudes and behaviour. (CUP 1968); Karl Marx, A Contribution to the Critique of Political Economy, Collected Works (1859, 1971 edition, Lawrence \& Wishart) p.210.
} 
working $^{37}$, and that formed the basis for Braverman's deskilling and degradation of work thesis.

Central to all of this is the mantra that tax-payers' cash should be used in the most efficient and effective way, and in labour-intensive services which are mainly personally delivered, this means a sustained push on worker performance. Critical to this version of public service management is that state-determined output targets within set budgets can be best achieved by senior management teams with enhanced powers and authority. This in turn implies a loss of autonomous decision making by those workers confronted with the realities of day-to-day working. ${ }^{38}$

There are a raft of studies that illustrate both the management pressures on frontline staff and their consequences in terms of staff performance. So managers need to secure actual from potential labour, and this deep-seated contradiction in the management of labour comes to a crisis over control at the point and moment of production. ${ }^{39}$ Efforts to overcome this rooted in Taylor's version of scientific management ${ }^{40}$ have spread into the public service work with lean production in the civil service $^{41}$, greater performance controls in probation, ${ }^{42}$ more intensive working for teachers, ${ }^{43}$ and ambulance staff. ${ }^{44}$ "Such labour management approaches

\footnotetext{
${ }^{37}$ Karl Marx and Frederick Engels, The German Ideology, Collected Works (Lawrence \& Wishart 1976 edition 1846) p.87.

${ }^{38}$ Thomas Diefenbach, 'New public management in public sector organizations: the dark sides of managerialistic 'enlightenment'. Public administration, 87:4 (2009), 892-909.

39 John Westergaard and Henrietta Resler, Class in a Capitalist Society: A Study of Contemporary Britain, (Heinemann Educational Books, 1975).

${ }^{40}$ Frederick W. Taylor, Scientific Management. (New York: Harper Bros.1911).

${ }^{41}$ Bob Carter, Andy Danford, Debra Howcroft, Helen Richardson, M, Andrew Smith, and Phil Taylor, 'All they lack is a chain': lean and the new performance management in the British civil service. New Technology, Work and Employment 26:2 (2011), 83-97.

${ }^{42}$ Jenny Gale, 'Government reforms, performance management and the labour process: the case of officers in the UK probation service', Work, Employment and Society, 26:5 (2012), 882-838.

${ }^{43}$ Bob Carter and Howard Stevenson, 'Teachers, workforce remodelling and the challenge to labour process analysis', Work, Employment and Society, 26:3 (2012), 481-496.

${ }^{44}$ McCann, L, Granter, E, Hassard, J and Hyde, P (2015a). Where next for the paramedic profession? An ethnography of work culture and occupational identity. Emergency Medicine Journal, 32 (5) e.6 -
} 
intensify exploitation and thereby increase alienation through the division of labour, giving rise to ever more precise performance management regimes". 45

In general terms the retreat from public ownership and welfarism has been most keenly felt in the public services themselves, and therefore, among public sector workers and their trade unions. When confronted with the specious arguments of 'modernisation' through which senior managers deliver the top-down political changes associated with budget cuts and private provision, staff have felt betrayed, ignored, and overwhelmed. All the basis for resistance. But resistance has been patchy and hard to organise into action as the fear of job loss in an era of high personal debt over-rides, some of the time in some places, the anger of pay cuts and loss of job satisfaction and associated quality of service provision to the citizenuser. $^{46}$

\section{Resistance and struggle - the role of unions:}

Trade unions have been variously defined as being a continuous (as opposed to sporadic) association of workers for the purpose of defending and advancing the terms and conditions (including pay and job security) of their members. The ways in which this is achieved tends to focus on collective bargaining in all its forms (official and unofficial; formal and informal; negotiations and industrial action). This bargaining takes place as between the union representing workers and managers representing employers. ${ }^{47}$ Some of the time the employers are themselves elected

e.7.; McCann, L, Granter, E, Hassard, J and Hyde, P (2015b). 'You can't do both-something will give': Limitations of the targets culture. Human Resource Management Journal 54(5): 773-791.

${ }^{45} \mathrm{Kim}$ Mather and Roger Seifert, 'The close supervision of Further Education lecturers: "You have been weighed, measured and found wanting"', Work Employment and Society, 28:1 (2014), 95-111.

${ }^{46}$ Miguel Martinez, 'Trade unions and employment relations in the context of public sector change: the public sector, "old welfare states" and the politics of managerialism', International Journal of Public Sector Management 20:1 (1988), 5-15

${ }^{47}$ GDH Cole, British Trade Unionism Today, (Gollanz 1939); Alan Hutt, British Trade Unionism: a Short History, (Lawrence \& Wishart 1975); Vic Allen, 'Trade Unions in Contemporary Capitalism', 
as in local government, and the government of the day takes over on behalf of public sector employers the role of de facto employer of last resort as with the recent junior hospital doctors' dispute in England. As the role of the state in industrial relations becomes more frequent and embedded as with pay controls, so unions seek to influence policy through links with political parties and through wider campaigns frequently based on notions of fairness and justice. ${ }^{48}$

In 2016 there were 6.2 million trade union members in the UK $(23.5 \%$ of the workforce). The last time the level was so low was in 1938, and the decline since the high point of 13.2 million members in 1979 has been uninterrupted. There is significant agonising about causes, especially whom is to blame, and also abundant studies on the characteristics of union members, inter alia, by gender, age, ethnicity, type of contract, type of employment, and education. None can disguise the continued downward movement in numbers and proportions, and the consequent shift in balance of members. There were 3.6 million union members in the public sector in 2016 (52.7\% density) which is much higher than in the private sector with 2.6 million members and a density of $13.4 \%$. Of course these are averages and disguise both the concentration of membership in certain occupations and sectors, and the corresponding power and influence of such unions. ${ }^{49}$ A majority of union members affiliated through their unions to the TUC are in the public sector, and this shift in the balance of unionised workers has important implications for policy and strategy.

Socialist Register (1964) pp. 157-174; Karl Marx, Wage Labour and Capital in Selected Works, (Progress Publishers 1969 edition, 1849), pp.150-174; Beatrice and Sidney Webb Industrial Democracy, (Longmans Green 1897) and Trade Unionism, printed by the authors 1894.

${ }^{48}$ See Bert Ramelson's brilliant pamphlets against incomes policies of the 1970s such as Social contract, cure all or con trick?(Communist Party 1974). For details see Roger Seifert and Tom Sibley, Revolutionary Communist at work: a political biography of Bert Ramelson (Lawrence \& Wishart 2012).

${ }^{49}$ Department for Business, Energy \& Industrial Strategy (2017) Trade Union Membership 2016 Statistical Bulletin, Crown Copyright. 
In the public sector there are 2.4 million women and 1.2 million men in unions with union presence in the workplace at over $80 \%$, and with collective agreement coverage at 59\%. Pay and conditions were traditionally determined through central and national collective bargaining machinery normally in the form of Whitely Councils or equivalents. ${ }^{50}$ In the early 1970 s the Conservative government when confronted with increasingly difficult decisions about the future pay of certain key groups formed a set of Pay Review Bodies (for doctors \& dentists; senior staff; armed forces). Later after bouts of industrial action Pay Review bodies were set up for nurses and allied professions (1987) and schoolteachers (1990). More recently prison officers (2001) and the police (2014) have been forced into such arrangements. ${ }^{51}$

Civil service pay is decided through collective bargaining at Agency level, while national systems still pertain in local government, the fire service, and in limited forms in further and higher education. Much of this has been eroded with pensions being reformed by central government across the board, the advent of employerlevel bargaining and performance-related pay, and the introduction of more casual and agency staff. This is not the place to discuss the details of each public sector union, with their unique stories, and neither can this paper cover all the intricacies of a variety of bargaining systems. Currently most public sector workers still have their pay and terms and conditions determined by some form of collective bargaining (including pay review). This national picture is tempered by a retreat at local level of union activity when faced by a significant attack on their rights to negotiate and represent. Nonetheless, union membership remains high and stable, especially

\footnotetext{
${ }^{50}$ Brigid van Wanrooy, Helen Bewley, Alex Bryson, John Forth, Stephanie Freeth, Lucy Stokes and Stephen Wood, The 2011 Workplace Employment Relations Study, (Department for Business, Energy \& Industrial Strategy 2011).

${ }^{51}$ For one analysis of pay review bodies see Geoff White, 'The pay review body system: its development and impact.' Historical Studies in Industrial Relations 9 (2000): 71-100.
} 
among occupational groups such as nurses, teachers, ambulance staff, and firefighters. Many union members in the central and local government have been moved into the private sector, and unions such as PCS and UNISON have followed their members into their new employment. This has come at some cost in terms of representation, membership density, and collective bargaining coverage.

As noted above, there is widespread evidence of discontent among public sector workers. While this is publicised when there is a pay claim and dispute, the real source of alienation remains workload, task distribution, and associated performance management systems. Excessive workloads due to staff shortages and lack of investment in relevant technologies has meant staff are unable to do their jobs and fulfil their work purpose. Senior managers constrained by government budget cuts and policy direction force through changes that are detrimental both to the citizenuser and those employed to deliver the service. Resistance comes in many forms including quitting the job as with teachers and nurses, fighting at the workplace for better outcomes as with civil servants and local government workers, taking part in strike action as with firefighters, and marching through London as with police officers. None of these are mutually exclusive, but such actions have forced the issue of service provision up the political agenda. They have highlighted the impact of staff cuts, pay reductions, and over-working on both staff and service users.

The resistance of the workforce to this combination of management pressures, structural reform, loss of pay and pensions, and changing labour process has been fitful and at times fraught. Union leaders in the form of both general secretaries and national executives have sought, in the main, to come together with local activists to push forward on four fronts: first to fight for better pay, conditions, and staffing levels; second, to reject the management-driven direction of travel of the services involved; 
third to re-affirm their vision of how the services should be funded, managed, and staffed.; and fourthly, they have sought common cause with other unions and the citizen-users involved in the services. In practice there have been resolutions at conferences, policy papers aimed at political groups and the wider interested public, campaigns and demonstrations, and various forms of industrial action. The latter has been sporadic and has taken the form of national strikes, local days of action, and variously overtime bans, work to rules, and intermittent short stoppages. ${ }^{52}$

In the UK, for example, there were widespread strikes in November 2011 involving up to 2 million workers in health, education, and from central and local government. This was over pension reforms and was accompanied by rallies. In May 2012 police, who cannot strike, marched through London in protest at their pay deals. In July 2014 nearly one million workers went out again over pay, pensions, and cuts in education, local government, and the fire service. In February 2015 firefighters took strike action over their pensions as part of a long-running dispute. PCS have been involved in a series of local and sector strikes mainly over job losses and office closures. Other unions have been involved in disputes over cuts and closures in local government, but one of the highest profile strikes was by junior hospital doctors (in 2016) over changes in weekend working. There have been many such actions throughout the UK by public sector workers over a range of issues, and varying from large-scale national events through sporadic local action (bin men in Birmingham in 2017), and to countless workplace demonstrations of anger and opposition.

All of these cases among many others illustrate the growing frustration with cuts in pay and services, but there are also thousands of negotiations on a weekly basis

\footnotetext{
${ }^{52}$ Deborah Foster and Peter Scott. "Conceptualising union responses to contracting out municipal services, 1979-97." Industrial Relations Journal 29, no. 2 (1998): 137-150.
} 
concerning workload and stress, discrimination and bullying, job losses and changes to contracts, health and safety issues, and over failures of service delivery. Much of this has become more difficult as employers with government support row back on trade union facility time, good faith negotiations, and with changes to strike laws. ${ }^{53}$ But struggle needs direction, coherence, and has to be based on real possibilities and solidarities, and not infantile calls for 'general strike now' ${ }^{54}$ Struggle can unite and educate, but it must be based on the social pathology of everyday working lives rather than on irrelevant slogans, fantasy politics of union renewal, and a disregard for the hardships and fears experienced in workplaces across the board.

For many, the way forward is through strengthening 'free' collective bargaining in which strong unions represent the majority of workers in a formal set of processes with their employer. This is best served unhampered by government restrictions and with a 'mutual gains' approach, after all collective bargaining is designed to avoid conflict. There is, quite rightly, an open debate about the future direction of collective bargaining and the ways in which Labour politics can help. The sine quo non is that collective bargaining remains the best mechanism for setting pay and terms and conditions and is the best vehicle through which workers and their unions can protect and advance their interests. Unfortunately some muddled thinking has been introduced into the wider debate. This takes two forms: first concerns the impact of successful collective bargaining on the firm, sector, and national economy. Some

\footnotetext{
${ }^{53}$ Keith Ewing, John Hendy, and Cad Jones, A Manifesto for Labour Law: towards a comprehensive revision of workers' rights, (Institute of Employment Rights 2015).

${ }^{54}$ Vladimir Lenin, Left-wing communism -- an infantile disorder, in Selected Works (Lawrence \& Wishart 1969 edition, 1920), pp. 516-581; Rosa Luxemburg, The mass strike, the political party and the trade unions, (Marxist Educational Society of Detroit 1925 edition, 1906); Georg Lukacs, History and class consciousness, (MIT 1968); Walter Korpi and Michael Shalev, 'Strikes, industrial relations and class conflict in capitalist societies', British Journal of Sociology 30:2 (1979), 164-187; Kerstin Hamann, Alison Johnston, and John Kelly, 'Unions against governments: Explaining general strikes in Western Europe, 1980-2006'. Comparative Political Studies. 46:9 (2013),1030-57.
} 
argue that "it is now no longer in doubt that that an efficient and productive economy is critically associated with strong workers' rights and high levels of collective bargaining coverage". ${ }^{55}$ This is both incorrect as the evidence remains unclear and points in several directions, and disingenuous since the focus of strong collective bargaining is to defend and improve workers' pay and terms and conditions rather than help to make profits and benefit the wider economy. In the public sector this means that strong bargaining may be at odds with ideologically-formulated ideas of a strong economy.

Furthermore, it is unclear how the institutions (legally enforced or not) of collective bargaining can have a beneficial impact per se. This applies to processes (negotiations, dispute resolution) which in and of themselves cannot aid the firm, the sector, or the national economy. Only the outputs from the processes can have such a possible impact, and they vary over time, sector, markets, region, and type of occupation. Such outputs, for example higher wages, better health \& safety, and less discrimination, are themselves partly determined by factors outside the control of the workforce, and collective bargaining is only one factor in the determination of such outcomes. The proposals therefore for some form of sector-based system ${ }^{56}$ are flawed from the outset. A better view of the future is to focus on the purpose of collective bargaining and trade unionism, namely the protection and advancement of pay and terms and conditions; and that rigidly defined and applied rules with some notion of one-fits-all is impractical and flies in the face of current realities.

Finally, the applicability of such remedies for public sector workers seems unclear as the impact on the unit of economic activity, the sector, and the national economy

\footnotetext{
${ }^{55}$ Ewing et al (2016) A Manifesto for Labour Law, p. 7; this argument is repeated on pages 10-11. 56 Ibid p.20
} 
would be indirect and hard to measure. Unions most involved in the public sector with strong occupational biases tend to focus, correctly, on the restoration of national bargaining with some traditional local variations. This is increasingly urgent as fragmentation, particularly in health, education, and civil services is threatening the core terms and conditions of those workers. Furthermore, no amount of legislation and embedded institutions can counter the rise of Academy Schools, civil service agencies, and 'independent' health trusts. In other words you cannot reinvent structures and institutional arrangements and impose them on sectors that have radically changed.

\section{So to conclude:}

We are in a period of growing inequality as the balance of class forces has been tilted towards the ruling class, and that breeds insecurity and leads to instability worldwide. This balance is changing with a resurgence of class politics in the labour movement, resistance at many levels to the outright abuses of power, and as the centre of class struggle moves back again to the public provision of services, investment, and redistribution. The role of unions can vary according to time and place, and not all calls for general strikes are either valid or revolutionary. The increased intensity of class struggle has been witnessed across the world and has become greater since the 2008 crash. Its political manifestations are both clear and present, both dangerous and confused, and both optimistic and pessimistic. Actual class struggle in the workplace is gaining momentum, especially in the public sector, as exploitation and alienation objectively push workers to the edge. As one centre of the class struggle, public sector unions in action are rooted in the same experiences of exploitation and alienation as other workers throughout the nation and the world. That is the basis for unity and common cause, and for fighting division and 
overcoming weakness, and for the development of labour movement policies and practices that feed of and add to the shift in the balance of class forces. 